\title{
Pemetaan Masalah Belajar Siswa SMK Negeri 3 Yogyakarta Dan Penyelesaiannya (Tinjauan Srata Kelas)
}

\author{
Hasan Bastomi \\ IAIN Kudus, Jawa Tengah, Indonesia \\ hasan@iainkudus.ac.id
}

\begin{abstract}
Abstrak
Penelitian ini bertujuan untuk mengungkap pemetaan masalah belajar siswa SMK Negeri 3 Yogyakarta dan penyelesaiannya ditinjauan dari srata kelas. Penelitian tentang masalah belajar siswa ini dilakukan dengan menggunakan pendekatan kulitatif dengan metode survey dengan jumlah sampel 292 untuk taraf kesalahan 5\%. Instrumen yang digunakan dalam mengungkap masalah belajar siswa adalah instrumen non tes daftar cek masalah (DCM) dan angket terbuka cara menyelesaikan masalah kemudian dianalisis dengan analisis deskriptif. Hasil penelitian menunjukkan bahwa siswa SMK Negeri 3 Yogyakarta mengalami masalah belajar denga prosesntase lebih dari 90\% dengan kelas XII mengalami masalah belajar terbesar dengan prosesntase 96\%, siswa kelas XI sebesar 95\% dan siswa kelas $\mathrm{X}$ sebesar $92 \%$. Fektor penyebab masalah belajar pada siswa SMKN 3 Yogyakarta adalah kurangnya kemampuan siswa untuk memanajemen waktu, perkembangan teknologi sehingga waktu belajar dihabiskan untu bermain game dan media social, serta padatnya jam belajar siswa SMK. Penyelesaian masalah belajar yang dilakukan siswa SMKN 3 Yogyakarta terdapat berbagai gaya penyelesaian masalah antara lain; berusaha menyelsaikan masalah, mencari dukungan sosial,dengan agama dan penyelesaian tidak produktif.
\end{abstract}

Kata Kunci: Masalah, Belajar, Penyelesaian

\begin{abstract}
Mapping of Problem Learning Problem Vocational School 3 Yogyakarta And Its Completion (Class Srata Review). This study aims to uncover the mapping of students' learning problems at SMK Negeri 3 Yogyakarta and their resolution is reviewed from the classroom. Research on student learning problems was conducted using
\end{abstract}


a qualitative approach with a survey method with a sample size of 292 for an error rate of 5\%. The instrument used in uncovering student learning problems is a non-test instrument check list problem (DCM) and an open questionnaire for how to solve problems then analyzed with descriptive analysis. The results showed that students of SMK Negeri 3 Yogyakarta experienced learning problems with a process of more than 90\% with class XII having the biggest learning problems with a process of $96 \%$, class XI students at $95 \%$ and class X students at 92\%. The factors that cause learning problems in SMKN 3 Yogyakarta students are the lack of students' ability to manage time, technological development so that learning time is spent playing games and social media, as well as the tight hours of study of SMK students. Learning problem solving by students of SMKN 3 Yogyakarta there are various styles of problem solving including; trying to solve problems, seek social support, with religion and unproductive solutions.

Keywords: Problems, Learning, Settlement

\section{A. Pendahuluan}

Pelaksanaan kegiatan proses belajar mengajar tidak terlepas dari berbagai masalah belajar. Salah satunya berkaitan dengan masalah keterampilan belajar. Menurut Syahril dan Riska Ahmad (1986: 28) masalah merupakan“ kegagalan individu dalam pemenuhan satu atau beberapa kebutuhan, sehingga menimbulkan ketidakseimbangan". Menurut Nana Sudjana (2005: 28) "belajar adalah suatu proses yang ditandai dengan adanya perubahan pada diri seseorang, perubahan sebagai hasil dari proses belajar dapat ditunjukkan dengan berbagai bentuk, seperti pengetahuan, pemahaman, sikap dan tingkah laku, kecakapan, kemampuan, daya kreasi, daya penerimaan dan lainnya yang ada atau terjadi pada individu tersebut".

Masalah merupakan ketidaksesuaian antara harapan dengan kenyataan, ada yang melihat sebagai tidak terpenuhinya kebutuhan seseorang, dan adapula yang mengartikannya sebagai suatu hal yang tidak mengenakkan atau sesuatu yang dapat menghambat seseorang dalam mencapai tujuannya. Prayitno (1992: 63) mengemukakan bahwa masalah adalah sesuatu yang tidak disukai adanya, 
menimbulkan masalah bagi diri sendiri dan atau orang lain, ingin atau perlu dihilangkan.

Masalah dapat muncul di mana saja, tak terkecuali dalam belajar. Dalam kegiatan belajar mengajar di sekolah ditemukan hal-hal berikut. Guru telah mengajar dengan baik. Ada siswa belajar dengan giat. Ada siswa pura-pura belajar. Ada siswa belajar setengah hati. Bahkan ada siswa yang tidak belajar. Dilihat dari hal-hal tersesbut dapat ditemukan adanya masalah-masalah belajar yang dialami oleh siswa.

Masalah belajar adalah suatu kondisi tertentu yang dialami oleh seorang individu yang menghambat kelancaran proses belajarnya, menurut Erman Amti dan Marjohan (1991: 67) mengungkapkan masalah belajar yang dialami oleh siswa berkaitan erat dengan keterampilan belajar. Menurut Herman Nirwana (2002: 77) "keterampilan belajar adalah suatu keterampilan yang harus dikuasai oleh seorang siswa untuk dapat sukses dalam menjalani pembelajaran di sekolah (sukses akademik) dengan menguasai materi yang di pelajarinya.

Tim Satgatsus 3SCPD (1997: 68) "mengemukakan beberapa jenis keterampilan belajar siswa yaitu keterampilan mengatur waktu belajar, keterampilan membaca buku, keterampilan menghafal pelajaran, keterampilan mengikuti pelajaran di kelas, keterampilan mencatat, keterampilan meringkas buku, keterampilan belajar kelompok, keterampilan mengingat, konsentrasi, dan ketahanan dalam belajar, keterampilan menyelesaikan tugas sekolah, keterampilan persiapan ujian". Keterampilan-keterampilan belajar yang telah disebutkan di atas semua sangat besar peranannya dalam meningkatkan hasil belajar siswa. Misalnya apabila siswa dalam mengatur waktu belajar tidak pandai maka akan berpengaruh terhadap belajarnya, selanjutnya apabila dalam membaca buku pelajaran siswa tidak memiliki keterampilan maka ia akan mengalami masalah dalam memahami bacaan buku tersebut, begitu juga seterusnya dengan keterampilan-keterampilan belajar yang lain. Fenomena di lapangan menemukan banyaknya siswa yang belum memiliki keterampilan belajar. Hasil pengolahan 
AUM PTSDL menemukan masalah paling banyak terdapat pada bidang keterampilan belajar 46,47\% dari 26 orang siswa (Syafni, 2012: 71).

Tugas utama seorang guru adalah membelajarkan siswa. Ini berarti bahwa bila guru bertindak mengajar, maka diharapkan siswa berajar atau belajar. Namun adakalanya didalam kegiatan belajar mengajar di sekolah sering ditemukannya masalah-masalah yang berkenaan dengan belajar yang dialami siswa tersebut. Masalah-masalah tersebut dipengaruhi oleh faktor internal (yang berasal dari dalam diri siswa itu sendiri) dan juga oleh faktor eksternal (yang berasal dari luar siswa itu sendiri).

Masalah-masalah yang dialami oleh siswa apabila tidak segera di atasi tentunya akan menghambat proses belajar siswa dan akan berdampak pada pencapaian tujuan dari belajar tersebut. Siswa akan berhasil dalam proses belajar apabila siswa itu tidak mempunyai masalah yang dapat mempengaruhi proses belajarnya. Jika terdapat siswa yang mempunyai masalah dan permasalahan siswa tersebut tidak segera ditemukan solusinya, siswa akan mengalami kegagalan atau masalah belajar yang dapat mengakibatkan rendah prestasinya/tidak lulus, rendahnya prestasi belajar, minat belajar atau tidak dapat melanjutkan belajar.

Dengan melihat berbagai hal yang terjadi pada masalah belajar tersebut di atas, melakukan penelitian tentang masalah belajar siswa dan penyelesaiannya menjadi satu tema yang cukup menarik. Terdapat empat hal yang secara teoritik menunjukkan bahwa penelitian tentang masalah belajar siswa dan penyelesaiannya menarik perhatian. Pertama, Pelaksanaan kegiatan proses belajar mengajar tidak terlepas dari berbagai masalah belajar. Kedua, masalah adalah sesuatu yang tidak disukai adanya, menimbulkan masalah bagi diri sendiri dan atau orang lain, ingin atau perlu dihilangkan. Ketiga, Masalah belajar adalah suatu kondisi tertentu yang dialami oleh seorang individu yang menghambat kelancaran proses belajarnya. Keempat, Masalah-masalah yang dialami oleh siswa apabila tidak segera di atasi tentunya akan menghambat proses belajar siswa dan akan berdampak pada pencapaian tujuan dari belajar tersebut. 
Tempat yang dianggap peneliti mampu mewadahi penelitian ini adalah SMK Negeri 3 Yogyakarta. Tempat ini merupakan sekolah yang dianggap cukup tua di Yogyakarta, sekolahan ini berdiri pada tahun 1965. Selain cukup lama berdiri, SMK Negeri 3 juga memiliki jumlah siswa dan kompetensi kejuruan yang tergolong banyak, yaitu dengan 1776 siswa dan 9 kompetensi keahlian. Tentunya dengan jumlah siswa serta kompetensi keahlian yang banyak tersebut, peneliti akan menemukan keragaman karakter siswa, terutama yang berkenaan dengan masalah masalah belajar siswa.

\section{B. Pembahasan}

\section{Masalah Belajar Siswa}

Masalah adalah ketidaksesuaian antara harapan dengan kenyataan, ada yang melihat sebagai tidak terpenuhinya kebutuhan seseorang, dan adapula yang mengartikannya sebagai suatu hal yang tidak mengenakan. Prayitno (1992: 62) mengemukakan bahwa masalah adalah sesuatu yang tidak disukai adanya, menimbulkan masalah bagi diri sendiri dan atau orang lain, ingin atau perlu dihilangkan. Sedangkan menurut pengertian secara psikologis, belajar merupakan suatu proses perubahan yaitu perubahan dalam tingkah laku sebagai hasil dari interaksi dengan lingkungannya dalam memenuhi kebutuhan hidupnya. Pengertian belajar dapat didefinisikan "Belajar ialah sesuatu proses yang dilakukan individu untuk memperoleh suatu perubahan tingkah laku yang baru secara keseluruhan, sebagai hasil pengalaman individu itu sendiri dalam interaksi dengan lingkungannya".

"Belajar adalah proses perubahan pengetahuan atau perilaku sebagai hasil dari pengalaman. Pengalaman ini terjadi melalui interaksi antara individu dengan lingkungannya (Woolfolk, 1995: 196). Menurut Garry dan Kingsley (1970: 5) Belajar adalah proses tingkah laku (dalam arti luas), ditimbulkan atau diubah melalui praktek dan latihan. Sedangkan menurut Gagne (1997: 77) bahwa "belajar adalah suatu proses dimana suatu organisasi berubah perilakunya sebagai akibat 
pengalaman". Dari definisi masalah dan belajar maka masalah belajar dapat diartikan atau didefinisikan sebagai berikut : "Masalah belajar adalah suatu kondisi tertentu yang dialami oleh murid dan menghambat kelancaran proses yang dilakukan individu untuk memperoleh suatu perubahan tingkah laku yang baru secara keseluruhan".

Kondisi tertentu itu dapat berkenaan dengan keadaan dirinya yaitu berupa kelemahan-kelemahan dan dapat juga berkenaan dengan lingkungan yang tidak menguntungkan bagi dirinya. Masalah-masalah belajar ini tidak hanya dialami oleh murid-murid yang lambat saja dalam belajarnya, tetapi juga dapat menimpa murid-murid yang pandai atau cerdas.

Dalam interaksi belajar mengajar siswa merupakan kunci utama keberhasilan belajar selama proses belajar yang dilakukan. Proses belajar merupakan aktivitas psikis berkenaan dengan bahan belajar. Adanya masalah belajar akan menimbulkan suatu keadaan di mana siswa tidak dapat belajar sebagaimana mestinya sehingga memiliki prestasi belajar yang rendah. Siswa yang mengalami masalah dengan belajarnya biasanya ditandai adanya gejala: (1) prestasi yang rendah atau di bawah rata-rata yang dicapai oleh kelompok kelas; (2) hasil yang dicapai tidak seimbang dengan usaha yang dilakukan; (3) lambat dalam melakukan tugas belajar (Hamalik, 2005: 13). Masalah belajar bahkan dapat menyebabkan suatu keadaan yang sulit dan mungkin menimbulkan suatu keputusasaan sehingga memaksakan seorang siswa untuk berhenti di tengah jalan. Adanya masalah belajar pada seorang siswa dapat dideteksi dengan kesalahankesalahan siswa dalam mengerjakan tugas maupun soal-soal tes. Kesalahan adalah penyimpangan terhadap jawaban yang benar pada suatu butir soal. Ini berarti masalah siswa akan dapat dideteksi melalui jawaban-jawaban siswa yang salah dalam mengerjakan suatu soal. Siswa yang berhasil dalam belajar akan mengalami perubahan dalam aspek kognitifnya. Perubahan tersebut dapat dilihat melalui prestasi yang diperoleh di sekolah atau melalui nilainya. Dalam kenyataannya 
masih sering dijumpai adanya siswa yang nilainya rendah. Rendahnya nilai atau prestasi siswa ini adanya masalah dalam belajarnya.

Menurut Hamalik (2005: 12) bahwa siswa yang secara potensial diharapkan akan mendapat nilai yang tinggi, akan tetapi prestasinya biasa-biasa saja atau mungkin lebih rendah dan teman lainnya yang potensinya lebih kurang darinya, dapat dipandang sebagai indikasi bahwa siswa mengalami masalah dalam aktivitasnya. Masalah belajar dapat diartikan sebagai segala sesuatu yang menghalangi atau memperlambat seorang siswa dalam mempelajari, memahami serta menguasai sesuatu.

Berdasarkan uraian di atas dapat disimpulkan bahwa masalah belajar adalah segala sesuatu yang membuat tidak lancar (lambat) atau menghalangi seseorang dalam mempelajari, memahami serta menguasai sesuatu untuk dapat mencapai tujuan. Adanya masalah belajar dapat ditandai dengan prestasi yang rendah atau di bawah ratarata yang dicapai oleh kelompok kelas, hasil yang dicapai tidak seimbang dengan usaha yang dilakukan dan lambat dalam melakukan tugas belajar. Siswa yang mengalami masalah belajar akan sukar dalam menyerap materi-materi pelajaran yang disampaikan oleh guru sehingga ia akan malas dalam belajar, serta tidak dapat menguasai materi, menghindari pelajaran, serta mengabaikan tugas-tugas yang diberikan guru.

Sedangkan faktor yang dapat menyebabkan masalah belajar di sekolah itu banyak dan beragam. Apabila dikaitkan dengan faktor-faktor yang berperan dalam belajar, penyebab masalah belajar tersebut dapat kita kelompokkan menjadi dua bagian besar, yaitu faktor yang berasal dari dalam diri siswa (faktor internal) dan faktor yang berasal dari luar diri siswa (faktor eksternal). Menurut Dalyono (1997: 239) menjelaskan faktor-faktor yang menimbulkan masalah dalam belajar, yaitu faktor intern atau faktor dari dalam diri siswa sendiri dan faktor ekstern yaitu faktor yang timbul dari luar siswa. 
a. Faktor Intern antara lain (1) Sebab yang bersifat fisik : karena sakit, karena kurang sehat atau sebab cacat tubuh. (2) Sebab yang bersifat karena rohani : intelegensi, bakat, minat, motivasi, faktor kesehatan mental, tipe-tipe khusus seorang pelajar.

b. Faktor Ekstern, antara lain; (1) Faktor Keluarga, yaitu tentang bagaimana cara mendidik anak, hubungan orang tua dengan anak. Faktor suasana : suasana sangat gaduh atau ramai. Faktor ekonomi keluarga : keadaan yang kurang mampu. (2) Faktor Sekolah, misalnya faktor guru, guru tidak berkualitas, hubungan guru dengan murid kurang harmonis, metode mengajar yang kurang disenangi oleh siswa. Faktor alat : alat pelajaran yang kurang lengkap. Faktor tempat atau gedung. Faktor kurilulum : kurikulum yang kurang baik, misalnya bahan-bahan terlalu tinggi, pembagian yang kurang seimbang, waktu sekolah dan disiplin kurang. (3) Faktor Mass Media dan Lingkungan Sosial, meliputi bioskop, TV, surat kabar, majalah, buku-buku komik. Lingkungan social meliputi teman bergaul, lingkungan tetangga, aktivitas dalam masyarakat.

Menurut Oemar Hamalik, (2005: 117) faktor-faktor yang bisa menimbulkan masalah belajar dapat digolongkan menjadi 4 (empat) yaitu

a. Faktor-faktor dari diri sendiri, yaitu faktor yang timbul dari diri siswa itu sendiri, disebut juga faktor intern. Faktor intern antara lain tidak mempunyai tujuan belajar yang jelas, kurangnya minat, kesehatan yang sering terganggu, kecakapan mengikuti pelajaran, kebiasaan belajar dan kurangnya penguasaan bahasa.

b. Faktor-faktor dari lingkungan sekolah, yaitu faktor-faktor yang berasal dari dalam sekolah, misal cara memberikan pelajaran, kurangnya bahan-bahan bacaan, kurangnya alat-alat, bahan pelajaran tidak sesuai dengan kemampuan dan penyelenggaraan pelajaran yang terlalu padat.

c. Faktor-faktor dari lingkungan keluarga, yaitu faktor-faktor yang berasal dari dalam keluarga siswa, antara lain kemampuan ekonomi keluarga, adanya 
masalah keluarga, rindu kampung (bagi siswa dari luar daerah), bertamu dan menerima tamu dan kurangnya pengawasan dari keluarga

d. Faktor-faktor dari lingkungan masyarakat, meliputi gangguan dari jenis kelamin lain, bekerja sambil belajar, aktif berorganisasi, tidak dapat mengatur waktu rekreasi dan waktu senggang dan tidak mempunyai teman belajar bersama.

\section{Bimbingan dan Konseling}

Konseling dari segi terminology, menurut James F. Adams, konseling adalah: "suatu pertalian timbal balik antara dua orang individu dimana yang seorang (counselor) membantu yang lain (counselee), supaya ia dapat lebih baik memhami dirinya dalam hubungan masalah-masalah hidup yang dihadapinya pada waktu itu dan yang akan datang (Arifin, 1976: 18).

Di samping itu istilah bimbingan selalu dirangkaikan dengan istilah konseling. Hal ini disebabkan karena bimbingan dan konseling itu merupakan suatu kegiatan yang integral (utuh atau melengkapi). Konseling merupakan salah satu teknik dalam pelayanan bimbingan diantara beberapa teknik lainnya. Bimbingan itu lebih luas dan konseling merupakan alat yang paling penting dari usaha pelayanan bimbingan. Pengertian konseling menurut terminologi diantaranya sebagai berikut:

1. Menurut James F Adams yang dikutip oleh I Djumhur dan Moh. Surya dikatakan bahwasanya: Konseling adalah suatu pertalian timbal balik antara dua orang individu di mana yang seorang (counselor) membantu yang lain (counselee), supaya ia dapat lebih memahami dirinya dalam hubungannya dengan masalah-masalah hidup yang dihadapi pada waktu itu dan pada waktu yang aka dating (Djumhur \& Surya, 1978: 29).

2. Menurut Bimo Walgio Konseling atau penyuluhan adalah bantuan yang diberikan kepada individu dalam memecahkan masalah kehidupannya dengan wawancara, dengan cara-cara yang sesuai dengan keadaan individu untuk mencapai kehidupannya (Walgito, 1989: 5). 
3. Menurut W.S. Winkel SJ Konseling merupakan suatu saluran bagi pemberian bimbingan. Dalam rangka konseling diadakan diskusi atau pembicaraan antara seorang penyuluh (counselor) dengan satu orang (individual counseling) atau dengan beberapa orang sekaligus (group counseling) (Winkel, 2005: 5).

Dari pendapat diatas penulis memberikan kesimpulan bahwa konseling merupakan satu pertalian timbal balik antara individu dalam memecahkan masalah kehidupannya untuk mencapai kesejahteraan hidupnya secara optimal.Jadi bimbingan menyangkut konseling dan sebaliknya konseling juga menyangkut bimbingan. Namun konseling disini diberikan secara kelompok seperti: bimbingan pada umumnya bagaimana cara belajar yang efesien dan dapat diberikan kepada seluruh kelas pada suatu waktu tertentu secara bersama-sama. Dari uraian-uraian dan teori-teori yang telah dikemukakan di atas maka dapatlah ditarik suatu kesimpulan yang efektif yaitu sebagai berikut: bimbingan konseling adalah suatu proses pemberian bantuan secara terus-menerus dalam perkembangan individual untuk mencapai kemampuan, pemahaman dan pengarahan diri, penyesuaian diri serta pemecahan masalah yang dihadapi, sehingga dapat bertindak wajar sesuai dengan tuntutan lingkungannya.

Proses Bimbingan dan Konseling di sekolah dapat berhasil apabila mempunyai tujuan yang jelas yang akan dicapainya.Bimbingan dan konseling bertujuan untuk membantu peserta didik agar dapat mencapai tujuan-tujuan perkembangannya yang meliputi aspek pribadi-sosial belajar (akademik) dan karir (Yusuf \& Nurihsan, 2006: 15).

Tujuan bimbingan dan konseling di sekolah dapat di kelompokkan menjadi tiga, yaitu: tujuan umum, tujuan khusus, dan tujuan akhir.

a. Tujuan bimbingan dan konseling secara umum:

Secara umum bimbingan dan konseling mempunyai tujuan yang sama dengan tujuan pendidikan, yaitu tercapainya perkembangan kepribadian yang optimal dan harmonis di antara unsure-unsurnya yang meliputi fisik,mental, emosional, social, dan moral, bahkan spiritual (religious). Apabila kebribadian 
telah berkembang secaraoptimal dan harmonis maka peserta didik dapat dikatakan telah dewasa. Tujuan pendidikan adalah kedewasaan, sedangkan tujuan bimbingan adalah kemandirian. Dalam ilmu pendidikan orang dewasa adalah orang yang mampu mandiri. Orang yang sudah mandiri adalah orang yang sudah mampu bertanggung jawab.

b. Tujuan bimbingan dan konseling secara khusus membantu siswa dalam: (1) Memahami dirinya, baik kekuatannya maupun kelemahannya. (2) Menentukan pilihan-pilihan yang tepat sebab kesalahan dalam menentukan pilihan dapat menimbulkan masalah baru yang mungkin lebih buruk. (3) Bimbingan dan konseling juga bertujan membantu siswa dalam mencari jalan keluar atau mengatasi masalah-masalah yang dihadapi siswa dalam kehidupannya, terumta kehidupan sekolah, aik yang menyangkut masalah belajar, masalah social, maupun masalah pribadi. (4) Hal yang penting diperlukan dalam kehidupan adalah penyesuaian diri. Bimbingan dan konseling berusaha memberikann pelayanan kepada siswa agar dapat menyesuaikan diri dengan lingkungannya, baik lingkungan alam, lingkungan sosial maupun lingkungan diri sendiri. (5) Di sekolah,bimbingan dan konseling di berikan agar siswa dapat mencapai prestasi yang optimal, khususnya prestasi belajar.

c. Tujuan akhir bimbingan dan konseling adalah agar siswa yang dibimbing dirinya sendiri(self-guidance). Individu dipandang telah mampu membing dirinya sendiri apabila: (1) Telah mampu memahami diri (self understanding) baik memahami kekuatan-kekuatannya ataupun kelemahan-kelemahannya. (2) Menerima dirinya (self acceptance) dengan segala kelebihan dan kekurangannya. (3) Dapat mengarahkan diri (self direction) kepada tujuan mulia yang bermanfaat bagi kehidupannya. (4) Mengaktualisasikan potensipotensi dirinya (self actualization, self realization) dengan cara-cara yang terpuji tanpa ada pihak-pihak yang merasa dirugikan. Apabila seseorang sudah beradapada keadaan demikian maka itulah yang dikatakan self-reliance, yaitu orang yang sudah mamu berdiri diatas kaki sendiri, orang yang mampu 
bertanggung jawab, orang yang sudah mandiri (independence).Kemandirian memungkinkan tercapainyakesejahteraan (walfare).Inilah tujuan akhir bimbingan dan konseling (Paimun, 2008: 19-21).

Dapat disimpulkan bahwa tujuan Bimbingan dan Konseling adalah untuk membantu siswa agar dapat memecahkan masalah yang dihadapinya dalam proses belajar mengajar, juga untuk dapat bersosialisasi dengan lingkungannya. Bimbingan dan koseling sebagai bagian dari keseluruhan program di sekolah mempunyai tertentu sejalan dengan pendidikan sekolah yang bersangkutan. Secara umum bimbingan bertujuan untuk membantu individu dalam mencapai tujuan yaitu: (1) Kebahagiaan hidup pribadi. (2) Kehidupan yang efektif dan produktif. (3) Kesanggupan hidup bersama orang lain. (4) Keserasian antara citacita siswa dengan kemampuan yang dimiliki (Gunarsa, 1988: 14).

Dari uraian di atas dapat diketahui bahwa tujuan bimbingan dan konseling adalah untuk mengembangkan potensi pada individu seoptimal mungkin, sesuai dengan kemampuan agar bisa menyesuaikan diri dengan lingkungannya, baik lingkungan sekolah, keluarga maupun lingkungan masyarakat.Dari keterangan diatas maka bisa disimpulkan bahwa tujuan konseling belajar sebagai berikut:Membantu siswa dalam menemukan cara-cara belajar yang efektif dan efisien, membantu siswa dalam merencanakan jadwal pelajaran secara efektif, menunjukkan cara-cara mempelajari suatu materi pelajaran, menunjukkan caracara membaca buku yang baik, membantu siswa dalam mengatasi masalah kesulitan belajar yang sedang dialami, menunjukkan cara pemanfaatan perpustakaan secara tepat, menunjukkan cara mempersiapkan diri dalam menghadapi ujian atau ulangan. Dalam hadits Nabi dijelaskan, yang artinya sebagai berikut: "Rasulullah SAW bersabda: Apabila suatu perkara diserahkan (pengelolaannya) kepada orang bukan ahlinya. Tunggu sajalah saat kehancurannya (ketidak berhasilannya)."(HR.Bukhari).

Maksud dari hadits tersebut adalah orang yang memberikan bimbingan konseling harus ahli/ prosfesional dalam bidang bimbingan konseling, supaya 
mencapai sasaran dan tujuan yang diharapkan. Apabila kegiatan bimbingan konseling dilaksanakan oleh orang yang bukan ahlinya, maka tidak akan mencapai hasilnya (Madhal, 2008: 152).

Sesuai dengan uraian sebelumnya bahwa bimbingan dan konseling bertujuan agar peserta didik dapat menemukan dirinya, mengenal dirinya dan mampu merencanakan masa depannya. Dalam hubungan ini bimbingan dan konseling berfungsi sebagai pemberi layanan kepada peserta didik agar masingmasing peserta didik dapat berkembang secara optimal sehingga menjadi pribadi yang utuh dan mandiri. Oleh karena itu pelayanan bimbingan dan konseling mengemban sejumlah fungsi yang hendak dipenuhi melalui kegiatan bimbingan dan konseling.

Bimbingan dan Konseling merupakan fungsi integral dalam proses belajar mengajar. Fungsi bimbingan Dewa Ketut Sukardi dalam bukunya Proses Bimbingan dan Penyuluhan di sekolah adalah:

a. Fungsi Preventif (Pencegahan) adalah merupakan fungsi pencegahan terhadap timbulnya masalah dalam fungsi bagi para siswa agar terhindar dari berbagai masalah yang dapat menghambat perkembangannya. Kegiatan yang berfungsi sebagai pencegahan berupa program orientasi, program bimbingan karier, invesasi data dan sebagainya.

b. Fungsi Penyaluran adalah fungsi agar para siswa yang dibimbing dapat berkembang secara optimal, siswa perlu dibanu mendapatkan kesempatan penyaluran pribadinya. Dalam fungsi penyaluran ini layanan yang dapat diberikan, misalnya memperoleh jurusan atau program yang tepat.

c. Fungsi Penyesuaian adalah membantu tercapainya penyesuaian antara pribadi siswa dan sekolah. Kegiatan dalam layanan fungsi ini berupa orientasi sekolah dan kegiatan-kegiatan kelompok.

d. Fungsi Perbaikan fungsi perbaikan berperan memberi bantuan bimbingan berusaha menghadapi masalah yang dihadapi siswa. 
Fungsi Pengembangan adalah layanan bimbingan dapat membantu para siswa dalam mengembangkan pribadinya secara terarah dan mantap. Dalam fungsi developmental ini hal-hal yang dipandang positif dijaga agar tetap baik dan mantap. Dengan demikian siswa dapat mencapai perkembangan kepribadian secara optimal (Sukardi, 1995: 8-9). Secara keseluruhan, jika semua fungsi-fungsi itu telah terlaksana dengan baik, dapatlah bahwa peserta didik akan mampu berkembang secara optimal pula. Keterpaduan semua fungsi tersebut akan sangat membantu perkembangan peserta didik.

\section{Metode Penelitian}

Penelitian tentang masalah belajar siswa ini dilakukan dengan menggunakan pendekatan kulitatif dengan metode survey. Menurut Irawan (2007: 101) disebutkan "metode survei adalah metode penelitian yang menggunakan koesioner sebagai instrumen utama untuk mengumpulkan data". Penetuan jumlah sample dalam penelitian ini menggunakan metode tabel yang dikembangkan oleh Isaac dan Michael dalam Sugiyono (2016: 86), berdasarkan tabel tersebut dapat dihitung jumlah sampel dari populasi 1776, untuk taraf kesalahan 5\% jumlah sampelnya adalah 292 dengan rincian jumlah sampel kelompok untuk kelas X 102 responden $(623 / 1776$ X 292=102,430), XI 95 responden $(578 / 1776$ X 292= 95,031), XII 95 responden (575/1776 X 292=94,538). Instrumen yang digunakan dalam mengungkap masalah belajar siswa adalah instrumen non tes daftar cek masalah (DCM) dan angket terbuka cara menyelesaikan masalah. Dari olah hasil daftar cek masalah (DCM) kemudian dianalisis dengan teknis analisis deskriptif yaitu mendeskripsikan data yang dikumpulkan berupa angka, kata-kata, dan gambar.

\section{Pemetaan Masalah Belajar Siswa SMKN 3 Yogyakarta dan Penyelesaiannya}

Untuk menentukan nilai kuantitatif pemetaan masalah pribadi-sosial siswa berdasarkan strata atau kelas adalah menggunakan skor jawaban angket dari responden sesuai dengan frekuensi jawaban dengan hasil sebagai berikut: 
Grafik pemetaan masalah belajar siswa

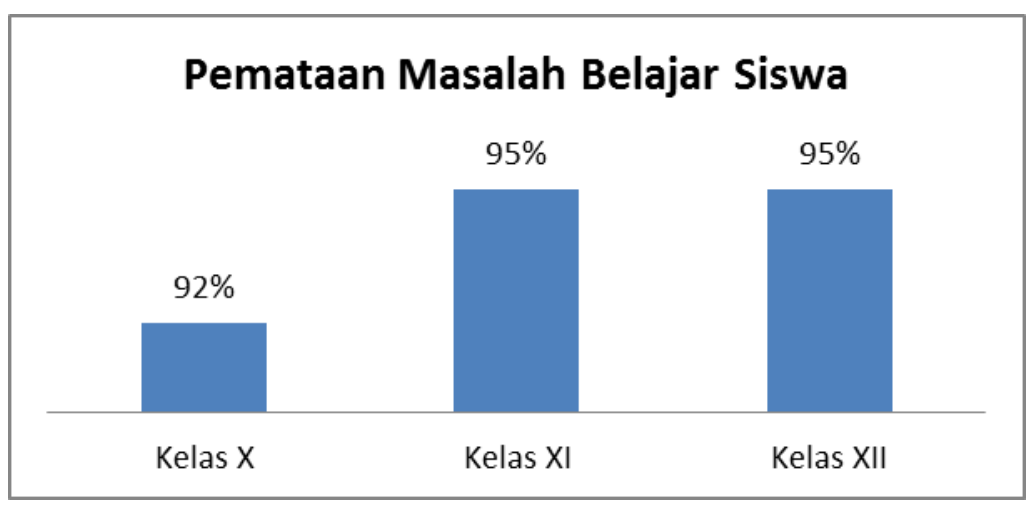

Dari data tersebut dapat diketahui bahwa siswa SMK Negeri 3 Yogyakarta mengalami masalah belajar denga prosesntase lebih dari $90 \%$ dengan kelas XII mengalami masalah belajar terbesar berjumlah 96\% dengan rincian 71\% belajar ketika ada ulangan, $86 \%$ siswa merasa waktu belajar tidak teratur, kemudian $49 \%$ belajar hanya ketika malam hari, $47 \%$ sukar memusatkan perhatian pada saat belajar dan $8 \%$ belajar hanya pada waktu malam hari.

Untuk kelas XI prosesntase masalah belajar sebesar 95\% dengan rincian 70\% belajar ketika ada ulangan, 85\% siswa merasa waktu belajar tidak teratur, kemudian $48 \%$ belajar hanya ketika malam hari, $46 \%$ sukar memusatkan perhatian pada saat belajar dan 7\% belajar hanya pada waktu malam hari. Sedangkan kelas X prosesntase masalah siswa 92\% dengan rincian $66 \%$ belajar ketika ada ulangan, 75\% siswa merasa waktu belajar tidak teratur, kemudian 55\% belajar hanya ketika malam hari, $52 \%$ sukar memusatkan perhatian pada saat belajar dan $6 \%$ belajar hanya pada waktu malam hari. Dan disajikan dalam grafik berikut:

\section{Garfik Rincian Masalah Belajar Siswa}




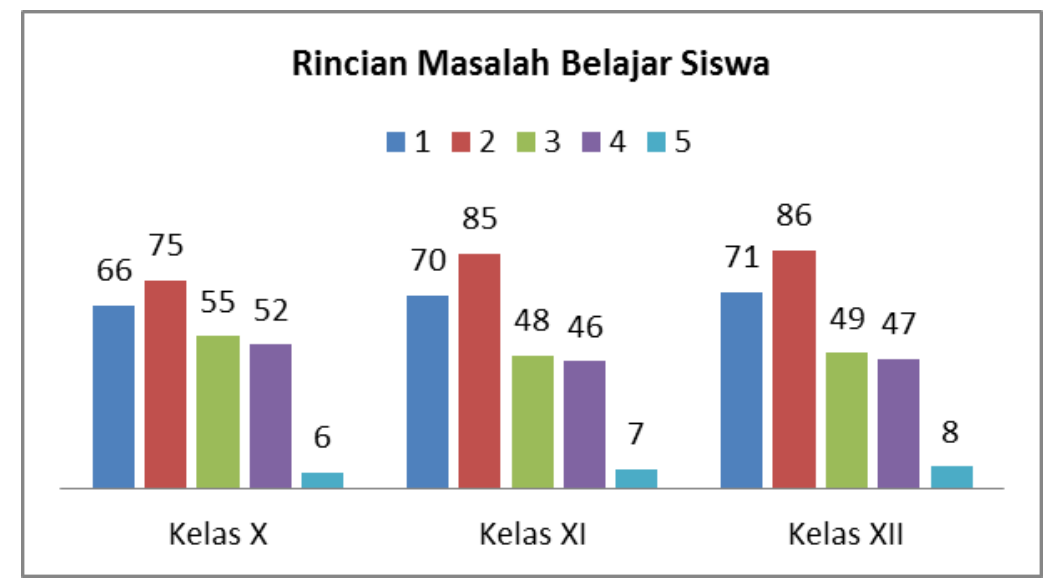

Belajar tidak tetarur dan belajar ketika ada ulangan merupakan masalah terbesar siswa, itu juga tidak dipungkiri oleh kesiswaan SMKN 3Yogyakarta. Mungkin tidak hanya siswa, perilaku seperti itu juga biasa dilakukan hamper tiap orang. Sedangkan untuk siswa yang belajar hanya malam hari tidak lepas dari masa remaja yang idialisme antara keinginan orang tua dan anak berbeda, hal tersebut tidak hanya di SMK, SMA juga demikian, seandainya ada siswa yang setiap malam itu belajar itu sekian persen dan sedikit sekali (Sungkowo, 2013).

Tidak teraturnya waktu belajar dan kebiasaan belajar jika ada ulangan itu dipengaruhi banyak faktor. Diantaranya adalah karena kemajuan teknologi, apalagi sekarang ini memang banyak godaan, semakin kesini teknologi semakin canggih, televisi semakin banyak chenelnya, kamudian penggunaan HP dan media sosial, sehingga dengan media menganggu siswa untuk belajar. Siswa hanya berorientasi bermain dan belum terarahkan, tetapi jika media digunakan untuk media belajar dan diarahkan oleh guru untuk belajar itu lebih baik, sehingga siswa dapat belajar menggunakan media teknologi (Mulyadi, 3013). Kemajuan teknologi juga menjadi tantangan pelajar kota Yogyakarta dan kota lainnya, dan hampir semua siswa belajarnya tidak teratur dan belajar ketika ada ulangan.

Masalah belajar menjadi tantangan bagi pelajar dikota Yogykarta, berdasarkan pengamatan hampir semua anak sekolah seperti mengalami maslah belajar. Apalagi sekarang ini yang namanya tantangan kemajuan IT atau gadged 
jauh lebih menyenangkan dari pada belajar, kecuali kalau anak-anak yang cerdas, bisa menjadikan media informasi untuk belajar. Tetapi hampir sebagian besar digunakan untuk game dan bermedia social dan itu sudah menjadi masalah umum dalam potret pendidikan. Bahwa tantangan televisi, media sosial dan lain-lain jauh melampui dari informasi yang diberikan dikelas sementara guru kurang memahami dan mengakses media informasi (Wiharto, 2013).

Tidak mampunya anak dalam memenejemen waktu dan kurangnya motivasi berprestasi juga merupakan faktor mengapa siswa waktu belajarnya tidak teratur dan belajar hanya pada saat ulangan saja. Karena siswa belum dapat melakukan menejemen waktu. Misalnya anak yang sering terlambat itu masalahnya karena mereka kebanyakan belum bisa mengelola waktunya. Berarti masalah belajar juga termasuk dalam ketidak mampuan siswa melakukan manajemen waktu. Masalah belajar sisiwa juga dapat diamati dari hasil evaluasi siswa, yang mana hasil ulangan siswa banyak kurang maksimal (Widiyati, 2013).

Padatnya jam pelajaran dan banyaknya jumlah mata pelajaran yang harus anak SMK lalui itu juga menjadi faktor mengapa siswa SMK belajarnya tidak teratur dan belajar ketika ada ulangan saja. Perbedaan anak SMK dan SMA/ MA semisal anak SMA/ MA itu pulang dapat teratur dengan jam pelajaran yang teratur, tetapi siswa SMK tidak demikan, siswa SMK disiapkan untuk menjadi pekerja sehingga mata pelajaran dan jam pelajaran sangat padat antara teori dan praktek Kadang sampai jam 15.00 baru pulang, kemudian sampai siswa merasa lelah, apalagi bagi siswa yang harus membantu orang tua mereka untuk mendapat maisah (pendapatan), jadi itulah yang menyebabkan belajar mereka tidak teratur (Wiharto, 2013).

Pola kualitas masalah dari tinjauan kelas menunjukkan bahwa kelas X itu memiliki rata-rata prosentase jumlah masalah yang rendah, kemudian di kelas XI dan kelas XII mengalami peningkatan. Pada Kelas X adalah masa penanaman karakter, kelas XI adalah masa peralihan sedangkan kelas XII masa dimana siswa banyak memiliki problem terkait dengan persiapan kelulusan (Mulyadi, 2013). 


\section{Penyelesaian masalah belajar siswa SMKN 3 Yogyakarta}

Sedangkan hasil cara penyelesaian maslah siswa ditinjau dari strata atau kelas yang telah disesuaikan gaya penyelesaian masalah siswa penyelesaian masalah dengan menyelesaikan masalah disimbolkan dengan angka 1, penyelesaian masalah dengan mencari dukungan orang lain disimbolkan dengan angka 2, penyelesaian dengan cara agama disimbolkan angka 3, dan penyelesaian masalah dengan cara non produktif disimbolkan dengan angka 4 dan masingmasing kelas memiliki perbedaan karakteristik dalam menyelesaikan masalah belajar yang dapat dilihat dalam tabel berikut;

Tabel gaya penyelesaian masalah siswa

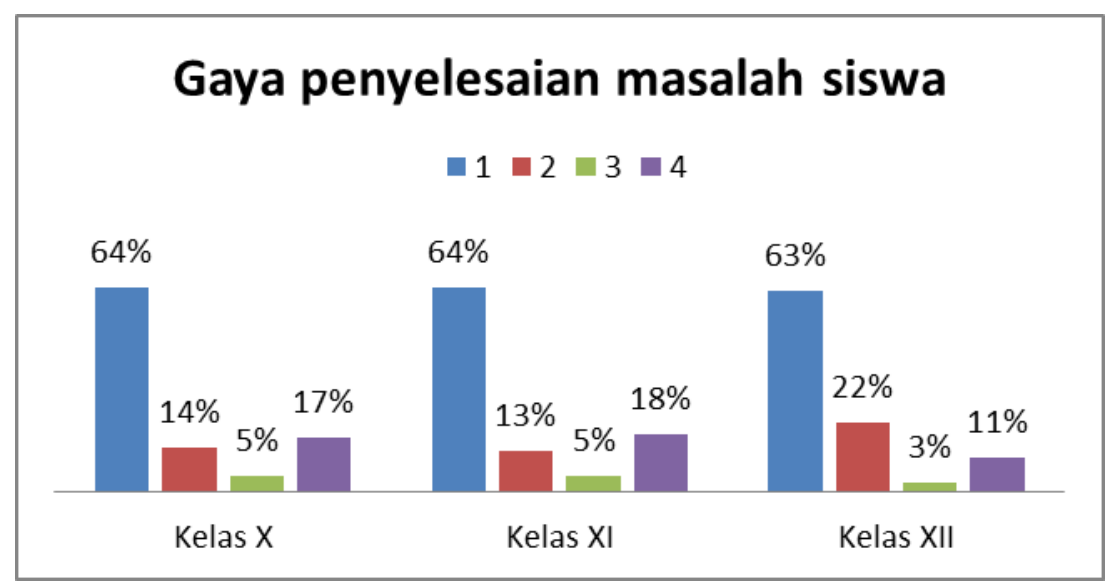

Dari data tersebut dapat dilihat bahwa 63-64\% siswa SMKN 3 Yogyakarta berusaha untuk menyelesaikan masalah belajar ketika ada masalah dengan rincian kelas X dan XI memiliki prosesntase yang sama yaitu 64\% dan kelas XII 63\%. Gaya penyelesaian masalah dengan berusaha menyelesaikan masalah belajar diimplementasikan dengan berusaha lebih keras dalam belajar, mencoba metode belajar, mengatur waktu belajar dan mengubah kebiasaan menjadi lebih baik. Selanjutnya 14-22\% siswa menyelesaikan maslah belajar dengan mencari dukungan orang lain dengan rincian kelas X 14\%, kelas XI 13\% dan kelas XII 22\%. Dukungan social ini dapat dimplementasikan mencari mencurahkan perasaan dengan teman, orang tua, guru dan guru BK. 
Agama juga dapat menjadi jalan bagi siswa SMKN 3 Yogyakarta dalam menyelsaikan masalah belajar dengan prosesntase 3-5\% dengan rincian kelas X dan XI memiliki prosesntase yang sama yaitu 5\% dan kelas XII 3\%. Minimnya siswa yang menyelesaikan masalah dengan agama dikarnakan keterbatasan siswa SMKN 3 Yogyakarta tentang pendidikan agama dan waktu belajar mereka yang panjang sehingga membuat mereka terbatas dalam melaksanakan ibadah atau ritual keagamaan. Sedangkan implementasi penyelesaian masalah dengan agama adalah dengan cara bersabar dan berdoa serta beribadah.

Terdapat pula siswa yang menyelesaikan masalahnya dengan cara non produktif seperti cuek dan tidak perduli serta menghindar dari masalah dengan prosesntase $11-18 \%$ dengan rincian kelas X 17\%, kelas XI 18\% dan kelas XII 11\%. Minimnya penyelesaian maslah dengan cara tidak produktif yang terdapat pada kelas XII adalah karena kedewasaan mereka dan sudah mulai serius untuk belajar menghadapi kelulusan.

\section{Simpulan}

Dari beberapa uraian sebelumnya dapat dikemukakan hal-hal berikut ini: pertama, siswa SMK Negeri 3 Yogyakarta mengalami masalah belajar denga prosesntase lebih dari 90\% dengan kelas XII mengalami masalah belajar terbesar berjumlah 96\% dengan rincian 71\% belajar ketika ada ulangan, 86\% siswa merasa waktu belajar tidak teratur, kemudian $49 \%$ belajar hanya ketika malam hari, $47 \%$ sukar memusatkan perhatian pada saat belajar dan 8\% belajar hanya pada waktu malam hari. Untuk kelas XI prosesntase masalah belajar sebesar 95\% dengan rincian 70\% belajar ketika ada ulangan, 85\% siswa merasa waktu belajar tidak teratur, kemudian $48 \%$ belajar hanya ketika malam hari, $46 \%$ sukar memusatkan perhatian pada saat belajar dan $7 \%$ belajar hanya pada waktu malam hari. Sedangkan kelas X prosesntase masalah siswa 92\% dengan rincian 66\% belajar ketika ada ulangan, 75\% siswa merasa waktu belajar tidak teratur, kemudian 55\% belajar hanya ketika malam hari, 52\% sukar memusatkan perhatian pada saat 
belajar dan 6\% belajar hanya pada waktu malam hari. Kedua, fektor penyebab masalah belajar pada siswa SMKN 3 Yogyakarta adalah kurangnya kemampuan siswa untuk memanajemen waktu, perkembangan teknologi sehingga waktu belajar dihabiskan untu bermain game dan media social, serta padatnya jam belajar siswa SMK. Ketiga, penyelesaian masalah belajar yang dilakukan siswa SMKN 3 Yogyakarta terdapat berbagai gaya penyelesaian masalah yang mana masing-masing kelas memiliki karakteristik tersendiri dalam menyelesaikan masalah yaitu dengan berusaha menyelesaikan masalah, mencari dukungan social baik dari orang tua, teman dan guru BK, agama dengan bersabar dan berdoa dan penyelesaiana masalah non produktif seperti cuek dan tidak perduli. Namun prosesntase gaya penyelesaian masalah terbanyak adalah siswa SMKN 3 Yogyakarta berusaha menyelesaikan maslahnya.

\section{DAFTAR PUSTAKA}

Amti, E., \& Marjohan. (1991). Bimbingan dan Konseling. Jakarta: Depdibud.

Arifin, M. (1976). Pokok-Pokok Pikiran Tentang Bimbingan dan Penyuluhan Agama di Sekolah dan Luar Sekolah. Jakarta: Bulan Bintang.

Dalyono. (1997). Psikologi Pendidikan. Jakarta: Rineka Cipta.

Djumhur, L., \& Surya, M. (1978). Bimbingan dan Penyuluhan diSekolah Guidance and Conseling. Bandung: Ilmu.

Gagne, R. M. (1997). Kondisi Belajar dan Teori Pembelajaran (Munandir, Trans.). Jakarta: Depdikbud Dirjen Pendidikan Tinggi.

Garry, R., \& Kingsley, H. L. (1970). The Nature and Conditions of Learning. New York: Prentice-Hall.

Gunarsa, S. (1988). Psikologi untuk Membimbing. Jakarta: Gunung Mulia.

Hamalik, O. (2005). Metode Belajar dan Kesulitan-Kesulitan Belajar. Bandung: Tarsito.

Irawan, P. (2007). Penelitian Kualitatif dan Kuantitatif untuk Ilmu-ilmu Sosial. Jakarta: Departemen Ilmu Administrasi Fakultas Ilmu sosial dan Ilmu Politik Universitas Indonesia.

Madhal, H. (2008). Hadits BKI. Yogyakarta: Amanah.

Nirwana, H. (2002). Belajar dan Pembelajaran. Padang: FIP UNP.

Paimun. (2008). Bimbinan dan Konseling. Jakarta: UIN Syarif Hidayatullah.

Prayitno, E. (1992). Psikologi Perkembangan. Jakarta: Depdiknas. 
Sudjana, N. (2005). Dasar-Dasar Proses Belajar Mengajar. Bandung: Sinar Baru Algesindo.

Sugiyono. (2016). Metode Penelitian Pendidikan Pendekatan Kuantitatif, Kualitatif dan $R \& D$. Bandung: Alfabeta.

Sukardi, D. K. (1995). Proses Bimbingan dan Penyuluhan di Sekolah. Jakarta: Rineka Cipta.

Syafni, E. (2012). Laporan Praktek Lapangan Kependidikan. Lintau Buo.

Syahril, \& Riska, A. (1986). Pengantar Bimbinga Dan Konseling. Padang: Angkasa Raya.

Tim Satgasus 3SCPD. (1997). Seri Latihan Keterampilan Belajar. Padang: Depdikbud. Walgito, B. (1989). Bimbingan dan Penyuluhan di Sekolah. Yogyakarta: Andi Offset.

Winkel, W. S. (2005). Bimbingan dan konseling di Institusi Pendidikan. Jakarta: Media Abadi.

Woolfolk, A. E. (1995). Educational Psychology. New York: Allyn \& Bacon.

Yusuf, S., \& Nurihsan, A. J. (2006). Landasan Bimbingan \& Konseling. Bandung: Remaja Rosdakarya.

Wawancara dengan Budi Sungkowo (kesiswaan). Dilaksanakan pada hari Jumat, 16 April 2015 pada pukul 14.00.

Wawancara dengan Eko Mulyadi (pembina OSIS). Dilaksanakan pada hari Jumat, 16 April 2015 pada pukul 15.00.

Wawancara dengan Muhammad Wiharto (Guru PAI). Dilaksanakan pada hari Kamis, 16 April 2015 pada pukul 09.00. 